\title{
Le Thesaurus de I'Image Médicale de Strasbourg 020
}

\section{A. Wackenheim \\ 4, rue Dotzinger, F-67000 Strasbourg}

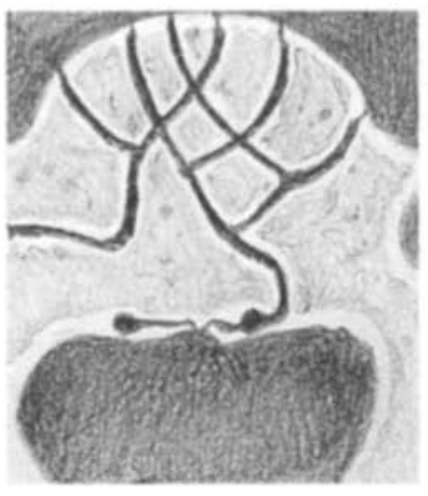

\section{D145}

Triple anastomotic veins of the cervical vertebral body with image of a puzzle (C) (CT)

Triple réseau de veines anastomotiques vertébrales corporéales cervicales avec image de puzzle (C) (TDM)

Dreifaches Venennetz der Y-förmigen anastomostischen Venen des zervikalen Wirbelkörpers mit Puzzle-Bild (C) (CT)

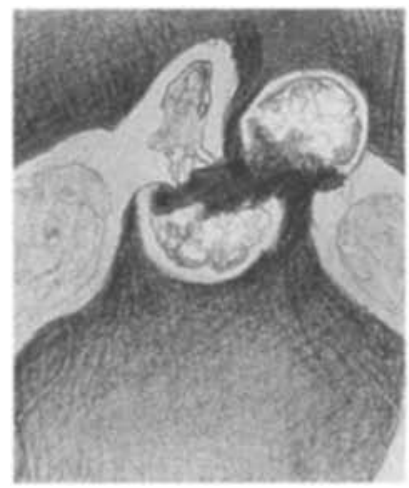

H57

Frontal (transverse) fracture of the dens axis associated to a sagittal fracture of the anterior arch of the atlas (P) (CT)

Fracture frontale (transversale) de la dent de l'axis associée à une fracture sagittale de l'arc antérieur de l'atlas (P) (TDM)

Frontale (transversale) Fraktur des Dens Axis mit einer sagittalen Fraktur des vorderen Atlasbogens (P) (CT)

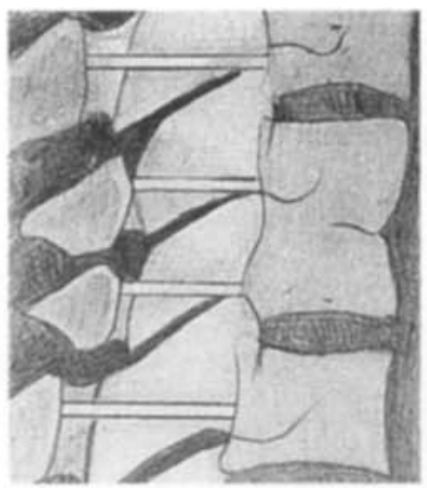

\section{G45}

Cervical block vertebra with hypoplasia of the posterior vertebral arches and constitutional canalar stenosis $(\mathrm{P})(\mathrm{RX})$

Bloc vertébral cervical corporéal avec hypoplasie de l'arc postérieure des deux vertèbres avec sténose constitutionnelle (P) (RX)

Zervikaler Wirbelblock mit Hypoplasie des hinteren Wirbelbogens und konstitutionelle Kanalstenose (P) (Rö)

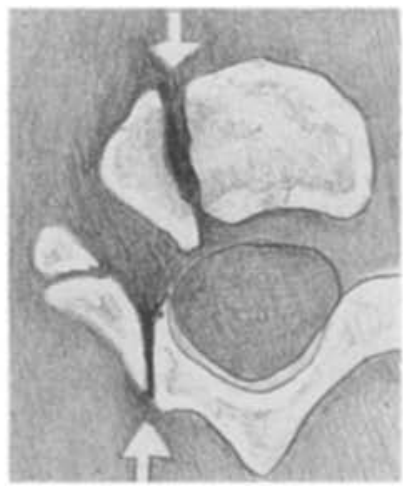

K5

Cervical parasagittal vertebral fracture of the body and of the posterior arch (P) (CT)

Fracture vertébrale cervicale parasagittale du corps et de l'arc postérieur (P) (TDM)

Zervikale parasagittale Wirbelfraktur des Körpers und des hinteren Bogens (P) (CT)

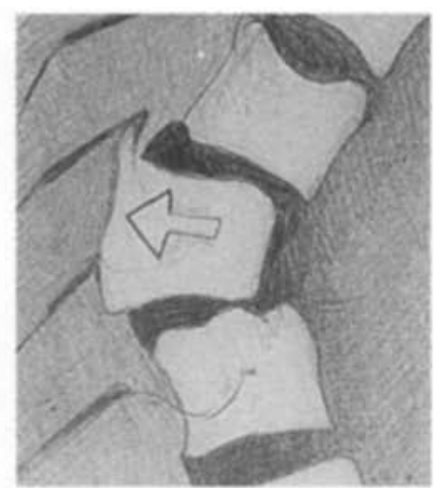

G46

Posterior enucleation of a cervical vertebra by double discal lesion in the flexed position of the head (S) (RX)

Enucléation postérieure d'une vertèbre en flexion par double lésion discale cervicale (S) $(\mathrm{RX})$

Posteriore Enukleation eines Halswirbels durch doppelte Diskusläsion bei der Flexion (S) (Rö)

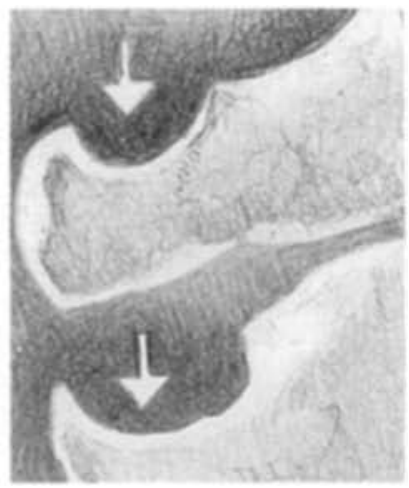

K6

Impression of the superior aspect of the spinous process of $\mathrm{C} 6$ and $\mathrm{C} 7$ by synovitis of polyarthritis (S) (RX)

Encoche du bord supérieur de l'apophyse épineuse de $\mathrm{C} 6$ et $\mathrm{C} 7$ par synovite rhumatoïde (S) (RX)

Einbuchtung am oberen Rand des Dornfortsatzes C6 und C7 durch Synovitis bei Polyarthritis (S) (Rö) 